\title{
Rider injury rates and emergency medical services at equestrian events
}

\author{
Bruce R Paix
}

\begin{abstract}
Background-Horse riding is a hazardous pastime, with a number of studies documenting high rates of injury and death among horse riders in general. This study focuses on the injury experience of cross country event riders, a high risk subset of horse riders.

Method-Injury data were collected at a series of 35 equestrian events in South Australia from 1990 to 1998.

Results-Injury rates were found to be especially high among event riders, with frequent falls, injuries, and even deaths. The highest injury rates were among the riders competing at the highest levels. Conclusion-There is a need for skilled emergency medical services at equestrian events.

(Br F Sports Med 1999;33:46-48)

Keywords: horse riders; equestrian; injury; eventing
\end{abstract}

The horse trial or event is a three phase competition that evolved over a hundred years ago as an all round test of military horsemanship. Phase one is the dressage test, an obedience test in which horse and rider complete a compulsory set of movements at a relatively low speed in a defined arena. Phase two is the cross country test, in which the horse and rider negotiate a series of solid obstacles while galloping across country (fig 1). Phase three is the show jumping test, a relatively easy final test in which the rider is asked to jump the horse over about a dozen lightweight obstacles, the intent being to show that the horse is still fit for service after the rigors of the cross country test.

Anecdotally, horse trials are a particularly dangerous form of horse sports, with frequent rider falls, injuries, and even deaths. Although these dangers have been noted in the past, ${ }^{1-3}$ this paper is the first to report specifically on the injury experience of a series of event riders in competition.

\section{Method}

Injury data were collected by myself acting as honorary medical officer at 35 equestrian competitions or events in South Australia from 1990 to 1998 , which represented about $10 \%$ of all events in South Australia over that period. I attended all events where a request from the organisers and freedom from other work commitments coincided. No attempt was made to randomise attendance at events, nor were statistics kept at events not attended by myself. The level of difficulty of the events ranged from the lowest level to that of the Australian Three Day Event Championships. Riders were classified as injured if they required medical treatment for a horse related injury during an event. Riders who were examined and not diagnosed with an injury, or who remounted without apparent injury after a fall, were classified as uninjured. Although no record was kept of falls that did not result in injury, anecdotally there were between five and ten falls per injury. Final injury data for riders who were referred to hospital were obtained by liaison with the receiving medical staff.

\section{Results}

There were 4220 competitors in the 35 events in this series. Of these, 37 were injured, an overall injury incidence of $0.88 \%$ per competitor per event. Of the 37 injured event riders, 11 were treated on the scene, and 26 were referred to hospital; 12 of the 26 referred to hospital were subsequently admitted.

Table 1 details the injuries sustained by the 37 injured riders. In keeping with other studies, ${ }^{4-7}$ head and neck injuries predominated (despite the universal use of approved helmets), being present in 19/37 cases. Other common injuries were lower limb fractures (3/37), rib fractures (3/37), and soft tissue injuries of the thoracolumbar spine (5/37). There was one fatal and one life threatening injury. Both occurred when the horse cartwheeled over a jump, falling on the rider. In the first case, the rider was evacuated directly from the course by helicopter but was dead on arrival at hospital despite immediate aggressive on-course medical care (cardiopulmonary resuscitation, intubation, bilateral needle thoracostomy, intravenous adrenaline, and fluid resuscitation via peripheral, central, and intraosseous cannulae). Post mortem examination disclosed ruptures of the aorta, liver, and diaphragm. In the second case, the rider was admitted to the intensive care unit with a flail chest injury and a pneumothorax. All 37 rider injuries occurred during the cross country phase, usually as a result of the rider falling from the horse, or from horse and rider both falling. In most cases, this occurred while jumping an obstacle.

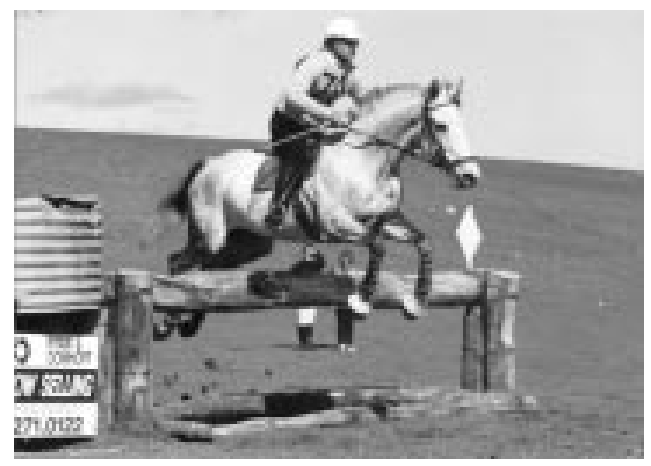

Figure 1 The author negotiating a typical obstacle during the cross country phase of an equestrian event. 
Table 1 Nature of injuries sustained by 37 injured riders at equestrian events

(1) Crush fracture of T4, T5, and T6 without neurological loss: admitted to hospital

(2) Bruised elbow: referred to hospital for $x$ ray: not admitted

(3) Closed head injury without loss of consciousness (LOC): treated at scene

(4) Closed head injury without LOC and multiple abrasions: treated at scene

(5) Lumbar disc prolapse: admitted to hospital

(6) Closed fracture of tibia and fibula: admitted to hospital

(7) Soft tissue injury to neck: referred to hospital for $x$ ray: not admitted

(8) Closed head injury with short LOC: admitted to hospital

(9) Severe flail chest injury and pneumothorax (16 broken ribs): admitted to ICU

(10) Fractured ankle: referred to hospital: not admitted

(11) Fractured ankle: admitted to hospital

(12) Soft tissue injury to lumbar spine: referred to hospital for $x$ ray: not admitted

(13) Multiple fractured ribs: admitted to hospital

(14) Fractured rib and wrist: referred to hospital: not admitted

(15) Bruised ribs: referred to hospital: not admitted

(16) Soft tissue injury to lumbar spine: referred to hospital: not admitted

(17) Closed head injury with short LOC: admitted to hospital

(18) Closed head injury without LOC and bruised hip: treated at scene

(19) Facial abrasions and mallet finger: treated at scene

(20) Facial abrasions: referred to hospital: not admitted

(21) Facial abrasions: treated at scene

(22) Facial abrasions: treated at scene

(23) Facial abrasions: treated at scene

(24) Facial abrasions: treated at scene

(25) Facial abrasions: treated at scene

(26) Soft tissue injury to neck: referred to hospital for $x$ ray: not admitted

(27) Fractured clavicle and hypotension: admitted to hospital

(28) Bilateral fractured thumbs: referred to hospital: not admitted

(29) Facial lacerations: admitted to hospital

(30) Closed head injury with short LOC: admitted to hospital

(31) Fractured wrist: admitted to hospital

(32) Soft tissue injury to lumbar spine: referred to hospital for $x$ ray: not admitted

(33) Bruised hip: referred to hospital for $x$ ray: not admitted

(34) Closed head injury with confusion but no LOC: treated at scene

(35) Closed head injury without LOC: treated at scene

(36) Fractured zygoma: referred to hospital: not admitted

(37) Ruptured aorta, liver, and diaphragm: helicopter evacuation to trauma centre: dead on arrival

Table 2 Injury incidence per rider in relation to difficulty of event ( $n=4220$ competitors)

\begin{tabular}{llllll}
\hline $\begin{array}{l}\text { Grade of } \\
\text { competition }\end{array}$ & $\begin{array}{l}\text { Maximum jump } \\
\text { height }(\mathrm{m})\end{array}$ & $\begin{array}{l}\text { Required speed } \\
(\mathrm{m} / \mathrm{min})\end{array}$ & $\begin{array}{l}\text { Treated at } \\
\text { scene }\end{array}$ & $\begin{array}{l}\text { Referred to } \\
\text { hospital }\end{array}$ & Total injured \\
\hline $\begin{array}{l}\text { "Advanced" + } \\
\text { "Intermediate" }\end{array}$ & 1.15 & 550 & $7 / 534$ & $5 / 534$ & $12 / 534(2.2)$ \\
$\begin{array}{l}\text { "Novice" + } \\
\text { "Grade One" }\end{array}$ & 1.10 & 525 & $4 / 1006$ & $11 / 1006$ & $15 / 1006(1.5)$ \\
"Pre-Novice" & 1.05 & 525 & $4 / 778$ & $2 / 778$ & $6 / 778(0.8)$ \\
"Grade Two" & 0.95 & 350 & $0 / 432$ & $0 / 432$ & $0 / 432(0)$ \\
"Grade Three" & 0.80 & 300 & $0 / 1177$ & $3 / 1177$ & $3 / 1177(0.3)$ \\
"Grade Four" & 0.65 & 274 & $0 / 293$ & $1 / 293$ & $1 / 293(0.3)$ \\
\hline
\end{tabular}

NB: These are Australian categories; nomenclature may differ elsewhere.

Values in parentheses are percentages.

Table 3 Medical services required at equestrian events

A doctor experienced in managing severe trauma

Equipment for resuscitation

Equipment for managing serious head, chest, and spinal injuries among competitors

Equipment for dealing with incidental medical emergencies among spectators

Plans for prompt road or air evacuation of casualties to appropriate trauma hospitals

EFFECT OF DIFFICULTY OF EVENT ON INCIDENCE

OF RIDER INJURY

The heights of the obstacles and the speed at which they are jumped increase progressively as the difficulty of the competition increases. There is a definite trend for increasing injury rates as the difficulty of the competition increases. The highest incidence of injury (2.2\% per competitor per event) occurred at the highest grade of competition (table 2).

\section{Discussion}

Horse riding is a dangerous pastime, on that the literature is clear. ${ }^{5-11}$ Estimates of injury rates among all classes of horse riders combined are generally of the order of one per thousand riding hours, ${ }^{12-16}$ an overall rate that suggests that horse riding is more dangerous than motorcycle riding. ${ }^{10}{ }^{17}$ Indeed, the overall injury incidence of $0.88 \%$ per competitor per event reported here exceeds by more than three times Chapman's reported incidence of $0.24 \%$ for motorcycle racers and $0.14 \%$ for car racers, ${ }^{18}$ suggesting that eventing is more dangerous than motorcycle racing!

In this series, 37 rider injuries occurred among 4220 competitors, and all occurred during the cross country phase. The time taken to complete this phase of a competition varies somewhat from event to event but is typically between five and 10 minutes. If an average time is assumed to be 7.5 minutes, one can calculate an overall injury rate for all event competitors of one per 14 hours of cross country riding.

At this rate, the cross country phase of an equestrian event is over 70 times as dangerous as horse riding in general. Furthermore, if the same average time of 7.5 minutes is assumed for the 534 competitors at the highest level, their rate of one injury per 5.5 hours is over 180 times that for all forms of horse riding combined.

On average, one competitor was injured at every event in this series. At one event, four competitors were admitted to hospital. At another, three were injured and one was killed, and the event was abandoned before the halfway stage. Concordant with studies of injured horse riders in general, , $^{515161920}$ injury severity among the injured event riders in this study was high, with over $70 \%(26 / 37)$ of the injured riders being referred to hospital and nearly half $(12 / 26)$ of those referred to hospital being admitted. It should be noted that equestrian events are frequently held in rural areas far from major hospitals. I routinely ascertain the capabilities of the local hospital in advance, particularly with regard to radiological facilities. In this study, 23 of 26 patients referred to hospital required $x$ ray examination. In addition, South Australia is served by an excellent aeromedical retrieval service, and, where appropriate, consideration is given to the direct admission of injured riders to a major trauma centre, with the designation of an on-course helicopter landing site and the briefing of its pilot in advance.

While the injury rates for cross country event riders are very high in comparison with horse riders in general, there are few comparative data from other branches of equestrian sport, although the reported career injury incidence among professional jockeys ranges from 2.4 to 15 per jockey. ${ }^{21}{ }^{22}$ Only professional rodeo riders, with a reported injury incidence (although mostly minor) of $11 \%$ per ride ${ }^{23}$ have a higher reported injury incidence than event riders.

In addition to the 37 traumatic injuries treated as above, I was also called to assist at four life threatening medical emergencies not directly related to horse riding, including chest pain in an official, an oropharyngeal bee sting in an allergic rider, and two episodes of severe asthma. This high rate of non-horse-related emergencies may be atypical but it should be noted that some events draw large crowds, over 42000 in the case of the 1997 Adelaide International Horse Trials, and that the medical facilities provided need to take account of this. 
CONCLUSIONS: REQUIREMENTS FOR EMERGENCY MEDICAL SERVICES AT EQUESTRIAN EVENTS

It is clear from the literature that horse riding is a dangerous sport, and the experience reported here suggests that cross country eventing is a particularly dangerous subset of this, more dangerous even than motorcycle or car racing. In consequence, appropriate emergency medical services are required during the cross country phases of equestrian events (table 3 ).

The event medical officer should be experienced in managing severe trauma, including loss of consciousness, and chest and spinal injury. Ideally this requirement would be met by a practitioner from the specialties of anaesthesia, emergency medicine, or intensive care, or by an experienced rural general practitioner. There should be appropriate emergency medical equipment, including that for resuscitation, intubation, intravenous therapy, and spinal and fracture immobilisation. There should also be supplies for dealing with incidental medical emergencies, notably anaphylaxis and asthma. Finally, plans should be in place for prompt casualty evacuation by road or air to the appropriate trauma hospital.

1 McLatchie GR, Lennox CME. Risks and injuries in horseriding sports. In: McLatchie GR, Lennox CME, eds. The soft tissues. London: Butterworth \& Heinemann, 1993.

2 McLatchie GR. Essentials of sports medicine, 2nd ed. Edinburgh: Churchill Livingstone, 1993.

3 Renstrom PAFH. Clinical practice of sports injury, prevenRenstrom PAFH. Clinical practice of sports injury, preven-
tion and care. In: The encyclopaedia of sports medicine $V$. Oxford: Blackwell Scientific, 1994.
4 Barone GW, Rogers BM. Pediatric equestrian injuries: a 14 year review. F Trauma 1989;29:245-7.

5 Ingemarson $\mathrm{H}$, Grevsten S, Thoren L. Lethal horse-riding njuries. F Trauma 1989;29:25-30.

6 Randall-Bond G, Christoph RA, Rogers BM. Pediatric equestrian injuries: assessing the impact of helmet use. Pediatrics 1995;95:487-9.

7 Buckley SM, Chalmers DJ, Langley JD. Injuries due to falls from horses. Aust $\mathcal{F}$ Public Health 1993;17:269-71.

8 Harrison CS. Fox hunting injuries in North America. Physician and Sportsmedicine 1984;12:130-4, 136-7.

9 Whitlock MR. Equestrian injuries: a comparison of professional and amateur injuries in Berkshire. Br f Sports Med 1987;21:25-6.

10 Firth J. Equestrian injuries. In: Schneider RC, Kennedy JC, Plant ML, eds. Sports injuries, mechanisms, prevention and treatment, 1st ed. Baltimore: Williams and Wilkins, 1985:431-9.

11 Mills NJ, Whitlock MD. Performance of horse-riding helmets in frontal and side impacts. Injury 1989;20:189-92.

12 Gierup J, Larsson M, Lennquist S. Incidence and nature of horse-riding injuries. Acta Chirurgica Scandinavica 1976; 142:57-61.

13 McLatchie GB. Equestrian injuries. $\mathrm{Br} \mathcal{F}$ Sports Med 1979;13:29-32.

14 Pounder DJ. The grave yawns for the horseman. Med f A ust 1984;411:632-5.

15 Nelson DE, Bixby-Hammett D. Equestrian injuries in children and young adults. American fournal of Diseases of Children 1992;146:611-14.

16 Nelson DE, Rivara FP, Condie C, et al. Injuries in equestrian sports. Physician and Sportsmedicine 1994;10:53-7, 59-60.

17 Nicholl JP. Safety of horseriding. BMF 1990;301:496.

18 Chapman MAS, Oni J. Motor racing accidents at Brands Hatch, 1988/9. Br F Sports Med 1991;25:121-3.

19 Barber HM. Horse-play: survey of accidents with horses. BMF 1973;3:532-4.

20 Lloyd RG. Riding and other equestrian injuries: considerable severity. Br F Sports Med 1987;21:22-4.

21 Press JM, Davis PD, Weisner SI, et al. The National Jockey Injury Study: an analysis of injuries to professional horse racing jockeys. Clin f Sports Med 1995;5:236-40.

22 Armijo M. Jockey injuries. Fockey News 1993:June/July.

2323 Griffin MS, Peterson KD, Halseth JR. Injuries in professional rodeo. Physician and Sportsmedicine 1983;11:110-16.

\section{Take home message}

Eventing is a dangerous sport, with frequent rider falls, injuries and even deaths. Skilled emergency medical services are required at equestrian events.

\section{Commentary}

This study has confirmed what many people believe, that eventing is the most dangerous of all equine sports. It should not, however, be interpreted as an unacceptable risk. The sport is very popular in Britain, with 8000 riders and 149 events each year. ${ }^{1}$ In the early season there are not enough competitions for the numbers wanting to compete. The organisers are receptive to improved safety and constantly amend problem fences. ${ }^{2}$ The rules also demand high protective equipment in comparison with some equestrian disciplines, although this is less strict for international competitions. ${ }^{3}$

Dr Paix highlights the need for adequate medical cover. This has improved since the Medical Equestrian Association was established in 1986, and there are now similar organisations in other countries. Trained paramedics with four wheel drive vehicles are mandatory for the sometimes difficult terrain. In England there is a problem in obtaining suitable medical cover, partly because of the large number of events and the fact that the doctor is rarely paid for his services. The Director of Badminton has attempted to improve training for doctors by organising an advanced trauma life support course, but most of the doctors who attended the first one in 1998 did not have the course fee reimbursed. The course has been criticised by some as not relevant to immediate care, but at least the idea is a first step towards improvement.

The deployment of doctors at a competition can be difficult because of large numbers of spectators and the length of time it may take to reach an injured rider. A proposal put forward for at least one of the large events that the less well trained doctors are at the fences and there is a fast response paramedical vehicle with skilled doctors may resolve some of the problems mentioned.

An additional problem for doctors that needs to be considered is how to asssess the fitness of a rider to continue riding immediately after a minor head injury. This may require a major change in the rules to improve safety, but is unlikely in the foreseeable future.

Eventing may involve amateur and professional riders in the same competition and is expensive and dangerous for all concerned. This paper shows that, despite a responsible attitude by the organisers, there is room for improvement in safety and medical cover.

British Horse Trials Association. Stoneleigh, Warwickshire.

MICHAEL WHITLOCK

2 Thomas H. Working party on safety in horse trials. Stoneleigh, Warwickshire: British Horse Trials Association, 1993.

3 British Horse Trials Association Rule Book 1998. Stoneleigh, Warwickshire. 